\title{
Purification and Electrophoretic analysis of Extracellular Alkaline Phosphatase from bulb extracts of Urginea species
}

\author{
Banani Misra $^{1^{*}}$, M.N. Shiva Kameshwari ${ }^{2}$ \\ ${ }^{1 *}$ Department of Botany, Bangalore University, Jnanabharathi Campus, Bengaluru, India \\ ${ }^{2}$ Department of Botany, Bangalore University, Jnanabharathi Campus, Bengaluru, India \\ *Corresponding Author: bananimisra561@gmail.com,Tel: +918884881000
}

Available online at: www.isroset.org

Received: 17/Mar/2018, Revised: 25/Mar/2018, Accepted: 21/Apr/2018, Online: 30/Apr/ 2018

\begin{abstract}
Alkaline phosphatase was purified from three species of Urginea collected from different regions of India, Urginea wightii (Yediyur), Urginea indica(Karwar) and Urginea polyphylla (Castle rock Poona). The procedure followed for purification were Salt precipitation, Dialysis, ion exchange and Gel filtration method. Lowry's method was used to estimate the Protein concentrations. The purified enzyme was subjected to 12.5\% SDS-PAGE for molecular determination of Urginea species. The molecular weight of the protein band obtained was nearly $46 \mathrm{kDa}$ in Urginea indica but Urginea wightii and Urginea polyphylla the protein band obtained was approximately $43 \mathrm{kDa}$. The enzyme activity in these three-species varied. In Urginea indica it was found to be more about $0.152 \mathrm{U} / \mathrm{ml}$ while in Urginea wightii showed $0.05 \mathrm{U} / \mathrm{ml}$ enzyme activity and $0.106 \mathrm{U} / \mathrm{ml}$. in Urginea polyphylla.
\end{abstract}

Keywords: Urginea, Alkaline Phosphatase, Purification, SDS-PAGE

\section{INTRODUCTION}

Isolation and characterization of enzymes is an important part of biochemistry. Although several enzyme isolation experiments have been described for this purpose we have found that Urginea Alkaline phosphatase is a unique and convenient enzyme system for such studies [1]. Alkaline phosphatase, ALP, ALKP, ALPase, Alk Phos or basic phosphatase is a homodimer protein. Each monomer contains five cysteine residues, two zinc atoms, and one magnesium atom crucial to its catalytic function. [2]. It is optimally active at alkaline $\mathrm{pH}$ environments. [3]. As its name indicates, ALP functions best under alkaline $\mathrm{pH}$ environments and has the physiological role of dephosphorylating compounds. The enzyme is found across a multitude of organisms, prokaryotes and eukaryotes alike, with the same general function but in different structural forms suitable to the environment [4]. In humans for example, it is found in many forms depending on its origin within the body - it plays an integral role in metabolism within the liver and development within the skeleton. Due to its widespread prevalence in these areas, its concentration in the bloodstream is used by diagnosticians as a biomarker.
Indian system of medicine has a long history of use, they have adequate scientific documentation, particularly in the light of modern scientific knowledge. Urginea is one of the extremely polytypic genus with about 100 species restricted to India, Africa and Mediterranean regions [5]. Wide genetic and chromosomal variations studies were made differentiate the different accessions of Urginea indica. The basic taxonomic work to higher developmental studies are still being explored in this genus. In India the genus is represented by about 9 species but only five species are recognized; Urginea indica, Urginea polyphylla, Urginea polyantha, Urginea razii,and Urginea wightii [6].

This medicinal plant has a great source for many organic compounds. The genetic Variability and genomic studies are still being a hot topic in research. Attempts has not been made so far on biochemical investigation involving protein and isozyme profile in this taxon. So, in the present study we had isolated extracellular alkaline phosphatase isozyme from bulb extracts of 3 different species of Urginea and studied the electrophoretic analysis. 


\section{MATERIALS AND METHODS}

\section{Collection of plant Material}

Three species of Urginea collected from different regions from India, Urginea wightii (Yediyur), Urginea indica(Karwar) and Urginea polyphylla (Castle rock Poona).

\section{Extraction}

Thirty grams of bulb of three species each were homogenized by using $30 \mathrm{ml}$ glycine alkaline buffer $\mathrm{pH} 8.8$ and was centrifuged at $10,000 \mathrm{rpm}$ for $10 \mathrm{~min}$ at $4^{\circ} \mathrm{C}$. Supernatant was used for the enzyme assay.

\section{Enzyme assay}

The enzyme assay was done by the stopped spectrophotometric rate determination [7]. In this method pNitrophenyl Phosphate is catalyze by alkaline phosphatase with presence of Water into p-Nitrophenol (pNPP) inorganic phosphate at $37^{\circ} \mathrm{C}$ and $\mathrm{pH}$ at 8.8 . The reaction mixture contains $0.5 \mathrm{ml}$ of $100 \mathrm{mM}$ Glycine Buffer with $1 \mathrm{mM}$ Magnesium Chloride and $0.5 \mathrm{ml}$ of substrate pNPP is mixed by inversion and equilibrate to $37^{\circ} \mathrm{C}$. After inversion $0.1 \mathrm{ml}$ enzyme solution was added and incubated for $10 \mathrm{~min}$ at $37^{\circ} \mathrm{C}$. The activity was stopped by adding $10 \mathrm{ml}$ of $20 \mathrm{mM}$ Sodium Hydroxide Solution). After stopping the reaction, the reaction mixed by swirling and transfer the solutions to suitable cuvettes and record the A410nm for both Test and Blank.

\section{Calculation:}

The activity was calculated by using the following formula

(A410nm Test - A410nm Blank) (11.1) (Df)

Units/ml enzyme $=$

$$
\text { (18.3) (0.1) (10) }
$$

Where $11.1=$ Volume (in milliliters) of assay, $\mathrm{Df}=$ Dilution factor, $18.3=$ Millimolar extinction coefficient of $\mathrm{p}$ nitrophenol at $410 \mathrm{~nm}, 0.1=$ Volume (in milliliters) of enzyme used, $10=$ Time of assay (in minutes) as per the Unit Definition

\section{Purification of Extracellular ALP.}

Cell free extract used for the purification by four step methods. Salt Precipitation, Dialysis, ion Exchange and Gel filtration.

\section{Ammonium sulphate fractionation}

The culture filtrate was centrifuged at $10,000 \mathrm{rpm}$ for $10 \mathrm{~min}$ at $4^{\circ} \mathrm{C}$ to remove suspended particles. The clear supernatant was treated with ammonium sulphate to get $70 \%$ saturation. Addition of ammonium sulphate was carried out with continuous stirring in an ice water bath, and then it was kept at $4^{\circ} \mathrm{C}$ for overnight. The precipitated protein was taken by centrifuge at $10000 \mathrm{rpm}$ for $20 \mathrm{~min}$ at $4^{\circ} \mathrm{C}$. The pellet obtained was dissolved in $10 \mathrm{mM}$ Tris buffer. The protein content of the fraction was determined by the method of Lowryet.al. [8].

\section{Dialysis}

Taken about $6 \mathrm{~cm}$ of the dialysis membrane and boil it in $100 \mathrm{ml}$ of distilled water for $10 \mathrm{~min}$ with slow stirring for activation (pre-treatment). Take out the membrane from the boiling water and place it in $100 \mathrm{ml}$ of solution containing boiling water with the addition of $2 \%$ sodium bicarbonate. Replace the activated membrane into a fresh beaker containing $100 \mathrm{ml}$ distilled water maintained at boiling temperature for further $5-10 \mathrm{~min}$. Take the activated membrane, tie it with rubber tightly on one side then pour the pellet which was dissolved in Tris $\mathrm{HCl}$ buffer after the tying the other side. The dialysis membrane was kept for overnight incubation. After the incubation the dialysis tube was kept on magnetic stirrer at 220-250 rpm for $3 \mathrm{hrs}$ in $500 \mathrm{ml}$ of $5 \mathrm{Mm}$ phosphate buffer with ice bath. The buffer was replaced by fresh $5 \mathrm{Mm}$ phosphate buffer every $60 \mathrm{~min}$. The dialysis process was continued till the end of $3 \mathrm{hrs}$.

\section{Ion exchange Chromatography}

After dialysis sample was subjected to anion exchange chromatography using DEAE cellulose (Genei Bangalore). It is one of the technique used in separation of Proteins and other Organic Compounds based on charge [9]. Change in $\mathrm{Ph}$ values from low to high shifts the surface charge of protein, the higher the net charge of the protein, the higher the ionic strength needed to bring about desorption [10]. Elution can generally be achieved by increasing the ionic strength (i.e conductivity) of the buffer with the solute for the charged sites of the ion exchange matrix; or changing the $\mathrm{PH}$ and thereby altering the charge of the solute. All procedures are carried out at $4^{\circ} \mathrm{C}$.

The $5 \mathrm{gm}$ of DEAE cellulose was suspended in $10 \mathrm{mM}$ Tris HCL buffer $\mathrm{pH}$ is 7.5 and kept at $4^{\circ} \mathrm{C}$ overnight. Swollen DEAE cellulose was loaded in to Chromatographic column $(2 \mathrm{cmX} 30 \mathrm{~cm})$ and allowed settle. Care was taking to avoid air bubbles in the column. Before loading, it was calibrated with $10 \mathrm{mM}$ Tris HCL $\mathrm{pH}$ 7.5. The dialyzed sample was poured to the column from the top. The unbounded proteins were washed in $10 \mathrm{mM}$ Tris HCl.The enzymes were eluted using gradently solution $(50 \mathrm{mM}$ to $200 \mathrm{mM}) 10 \mathrm{ml}$ of Solution A (50 mM Tris $\mathrm{HCl}+50 \mathrm{mM} \mathrm{NaCl})$. The elutants were collected in the same test tubes. The process of elution 
was carried out using solutions B $(50 \mathrm{mM}$ Tris HCL +75 $\mathrm{mM} \mathrm{NaCl}), \mathrm{C}(50 \mathrm{mM}$ Tris HCL $+75 \mathrm{mM} \mathrm{NaCl}), \mathrm{D}(50$ $\mathrm{mM}$ Tris $\mathrm{HCl}+100 \mathrm{~mm} \mathrm{NaCl}), \mathrm{E}(50 \mathrm{~mm}$ Tris $\mathrm{HCL}+150$ $\mathrm{mM} \mathrm{NaCl}$ ) and $\mathrm{F}(50 \mathrm{mM}$ Tris $\mathrm{HCL}+175 \mathrm{mM} \mathrm{NaCl}) . \mathrm{G}$ $(50 \mathrm{mM}$ Tris HCL $+200 \mathrm{mM} \mathrm{NaCl})$. Flow rate was adjusted to $1 \mathrm{ml} / 5 \mathrm{~min}$ and fraction was collected. Each fraction was analyzed for enzyme activity and Protein at $280 \mathrm{~nm}$. Active fraction was pooled and stored at $4^{0} \mathrm{C}$ for the

\begin{tabular}{|l|l|l|l|l|}
\hline Samples & $\begin{array}{l}\text { OD @ } \\
410 \mathrm{~nm}\end{array}$ & $\begin{array}{l}\text { Enzyme } \\
\text { activity } \\
(\mathrm{U} / \mathrm{ml})\end{array}$ & $\begin{array}{l}\text { Protein } \\
\text { Conc } \\
(\mathrm{Mg})\end{array}$ & $\begin{array}{l}\text { Specific } \\
\text { activity } \\
(\mathrm{U} / \mathrm{mg})\end{array}$ \\
\hline $\begin{array}{l}\text { Urginea } \\
\text { indica }\end{array}$ & 0.299 & 0.152 & 0.054 & 2.8 \\
\hline $\begin{array}{l}\text { Urginea } \\
\text { wightii }\end{array}$ & 0.131 & 0.050 & 0.080 & 0.63 \\
\hline $\begin{array}{l}\text { Urginea } \\
\text { polyphylla }\end{array}$ & 0.224 & 0.106 & 0.056 & 1.9 \\
\hline Control & 0.048 & ------ & ----- & ----- \\
\hline
\end{tabular}

further studies.

\section{Gel Filtration Chromatography}

Gel filtration is well suited for biomolecules that may be sensitive to changes in $\mathrm{pH}$, concentration of metal ions or co-factors and harsh environmental conditions. Separations can be performed in the presence of essential ions or cofactors, detergents, urea, guanidine hydrochloride, at high or low ionic strength, at $37^{\circ} \mathrm{C}$ or in the cold room according to the requirements of the experiment. Purified proteins can be collected in any chosen buffer. All procedures are carried out at $4^{\circ} \mathrm{C}$.

The $5 \mathrm{gm}$ of Sephadex G-100 was suspended in $10 \mathrm{mM}$ Tris HCL buffer $\mathrm{pH}$ is 7.5 and kept at $4^{\circ} \mathrm{C}$ overnight. Swollen Sephadex G-100 was loaded in to Chromatographic column $(2 \mathrm{cmX} 30 \mathrm{~cm})$ and allowed settle. Care was taking to avoid air bubbles in the column. Before loading it was calibrated with $10 \mathrm{mM}$ Tris HCL pH 7.5. The Ion exchanged sample was poured to the column from the top. Flow rate was adjusted to $1 \mathrm{ml} / 5 \mathrm{~min}$ by using $50 \mathrm{mM}$ Tris $\mathrm{HCl}$ and fraction was collected. Each fraction was analyzed for enzyme activity and Protein at $280 \mathrm{~nm}$. Active fraction was pooled and stored at $4^{0} \mathrm{C}$ for the further

\section{Molecular weight determination by PAGE}

\section{SDS-PAGE}

The purified enzyme was subjected to electrophoretic studies. Both Native and SDS (sodium dodecyl Sulphate)
PAGE was done in $12.5 \%$ gels [11]. The gels were prepared using a slab apparatus (Genei) with notched plate system. Gels of $1 \mathrm{~mm}$ thickness were by using perplex spaces of the same size. Molecular mass standards from Genei (Bangalore, India) was used as a marker. Protein were stained with Commasive Brilliant Blue G-250.

\section{RESULT AND DISCUSSION}

The crude extract of three different species of Urginea bulb collected from different regions of Karnataka was subjected to alkaline phosphatase assay by spectrophotometric method. According to the result, the activity of ALP was maximum in Urginea indica $(A)(0.152 \mathrm{U} / \mathrm{ml})$ with specific activity $2.8 \mathrm{U} / \mathrm{ml}$, where the concentration of protein was found to be $0.054 \mathrm{mg}$. Urginea wightii (B)showed the minimum enzyme activity $(0.050 \mathrm{U} / \mathrm{ml})$ with specific activity $0.63 \mathrm{U} / \mathrm{ml}$ and highest concentration of protein $(0.080 \mathrm{mg})$. Comparatively in Urginea Polyphylla, (C) the enzyme activity was found to be moderate $(0.106 \mathrm{U} / \mathrm{ml})$ with $1.9 \mathrm{U} / \mathrm{ml}$ specific activity and protein concentration of $0.056 \mathrm{mg}$ (Table 1).

\section{Table-1 Enzyme and protein Concentration of three species of Urginea}

The enzyme was purified by involving 4 step methods i.e. Ammonium sulphate fraction, dialysis, gel filtration chromatography and ion exchange chromatography.

Ammonium sulphate fraction is salting out method commonly used for protein precipitation and the unwanted proteins can be salted out [12]. The crude extract of 3 different species of Urgenia bulb was treated with ammonium sulphate to get $70 \%$ saturation.). According to the result reported in table 2 , the specific activity of Urginea indica was increased maximum to $3.6 \mathrm{U} / \mathrm{ml}$ from $2.8 \mathrm{U} / \mathrm{ml}$ with enzyme activity 0.210 , protein concentration $0.057 \mathrm{mg}$ and fold purification 1.3. The specific activity of Urginea wightii increased from $0.63 \mathrm{U} / \mathrm{ml}$ to $2.04 \mathrm{U} / \mathrm{ml}$ with $0.050 \mathrm{U} / \mathrm{ml}$ enzyme activity and highest protein concentration $(0.102 \mathrm{mg})$ and maximum of 3.2-fold purification(Table-3). Urginea polyphylla also showed the increase in enzyme activity, protein concentration, specific activity and fold purification as $0.126 \mathrm{U} / \mathrm{mi}, 0.080 \mathrm{mg}$, 2.44(U/mg) and 1.28 respectively(Table-4).

The desalted extracts were subjected to dialysis against $5 \mathrm{Mm}$ phosphate buffer all the three different species did not show much increase in enzyme activity and protein concentration, but the specific activity was increased to 3.9 $\mathrm{U} / \mathrm{ml}$ in Urginea indica, $2.7 \mathrm{U} / \mathrm{ml}$ in Urginea wightii and 2.9 $\mathrm{U} / \mathrm{ml}$ in Urginea polyphylla with maximum fold purification in Urginea wightii (4.2) and minimum in Urginea polyphylla (1.52) and Urginea indica (1.4). 
The dialysed extracts were again subjected to gel filtration and ion exchange chromatography. The five $\mathrm{ml}$ of dialysed extract were eluted at the rate of $1 \mathrm{ml} / 5 \mathrm{~min}$ from G- 100 Sephadex column suspended in $10 \mathrm{mM}$ tris HCL buffer with $\mathrm{pH}$ 7.5. The fractions were collected, pooled and analysed for enzyme activity and protein concentration. From the result it is determined that the alkaline phosphatase enzyme activity, specific activity and purification fold was increased to maximum in all the three samples. In contrast, in gel fitration chromatography protein concentration was decreased to $0.017 \mathrm{mg}$ in Urginea indica, 0.014 in Urginea wightii and 0.010 in Urginea polyphylla .

The pooled samples were eluted from DEAE cellulose column by linear gradient of $\mathrm{NaCl}$ and the flow rate was adjusted to $1 \mathrm{ml} / 5 \mathrm{~min}$. The fractions were pooled and analysed again for enzyme activity and protein concentration at $280 \mathrm{~nm}$. A significant increase in specific activity was observed in all the samples with maximum increase in Urginea polyphylla, Urginea indica and Urginea polyphylla $(15.7 \mathrm{U} / \mathrm{ml}, 13.7 \mathrm{U} / \mathrm{ml}$ and $10.3 \mathrm{U} / \mathrm{ml})$ with fold purification 4.9 (sample A) 16.3 in Urginea wightii and 8.2 in Urginea polyphylla. Although the samples showed a slight increase in enzyme activity, protein concentration remained same in all the 3 samples.

After purification Enzyme activity and protein concentration of all the three species were shown in Graph 1 and Graph -2.

\section{Graph:1 Protein Conc. Of three species of Urginea}

\section{Purified Protein graph of three species of Urginea}

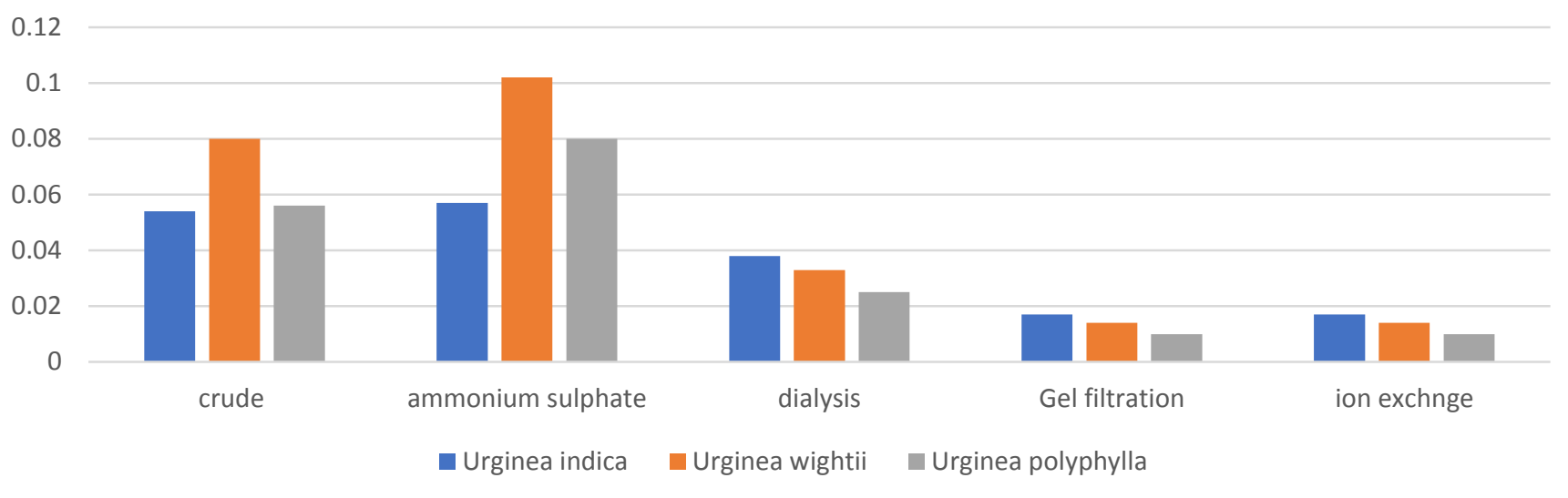

Graph:2 Enzyme conc. of three species of Urginea

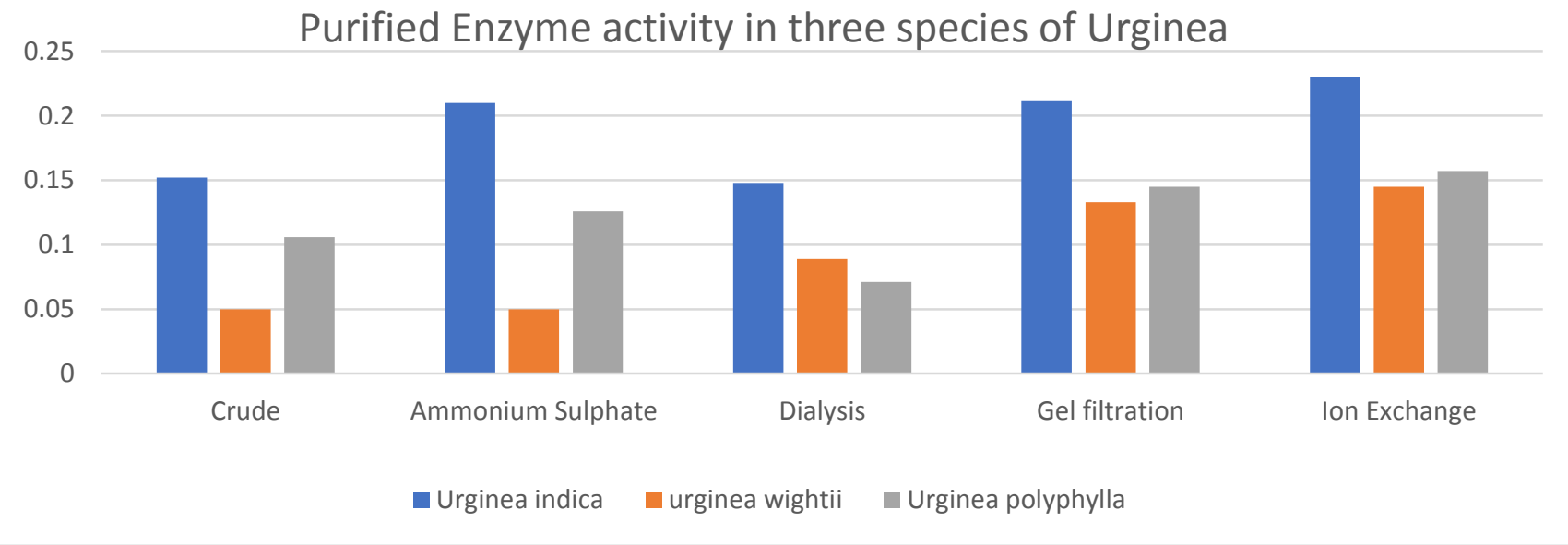


After each purification steps the enzyme activity, Protein concentration, specific activity, Fold purification of $U$ rginea indica, Urginea wightii, and Urginea polyphylla were shown in Table-2, Table-3 and Table-4 respectively.

Table-2 Purification table of Urginea indica

\begin{tabular}{|l|l|l|l|l|}
\hline Samples & $\begin{array}{l}\text { Enzyme } \\
\text { activity(U/ml) }\end{array}$ & $\begin{array}{l}\text { Protein Conc } \\
(\mathrm{Mg})\end{array}$ & $\begin{array}{l}\text { Specific } \\
\text { activity(U/mg) }\end{array}$ & $\begin{array}{l}\text { Fold } \\
\text { Purification }\end{array}$ \\
\hline Crude & 0.152 & 0.054 & 2.8 & 1 \\
\hline $\begin{array}{l}\text { Ammonium } \\
\text { Sulphate }\end{array}$ & 0.210 & 0.057 & 3.6 & 1.3 \\
\hline Dialysis & 0.148 & 0.038 & 3.9 & 1.4 \\
\hline Gel filtration & 0.212 & 0.017 & 12.4 & 4.4 \\
\hline Ion Exchange & 0.230 & 0.017 & 13.7 & 4.9 \\
\hline
\end{tabular}

Table-3: Purification Table of Urginea wightii

\begin{tabular}{|l|l|l|l|l|}
\hline Samples & $\begin{array}{l}\text { Enzyme } \\
\text { activity(U/ml) }\end{array}$ & $\begin{array}{l}\text { Protein Conc } \\
(\mathrm{Mg})\end{array}$ & $\begin{array}{l}\text { Specific } \\
\text { activity(U/mg) }\end{array}$ & $\begin{array}{l}\text { Fold } \\
\text { Purification }\end{array}$ \\
\hline Crude & 0.050 & 0.080 & 0.63 & 1 \\
\hline $\begin{array}{l}\text { Ammonium } \\
\text { Sulphate }\end{array}$ & 0.050 & 0.102 & 2.04 & 3.2 \\
\hline Dialysis & 0.089 & 0.033 & 2.7 & 4.2 \\
\hline Gel filtration & 0.133 & 0.014 & 9.5 & 14.8 \\
\hline Ion Exchange & 0.145 & 0.014 & 10.3 & 16.3 \\
\hline
\end{tabular}

Table-3: Purification Table of Urginea polyphylla

\begin{tabular}{|l|l|l|l|l|}
\hline Samples & $\begin{array}{l}\text { Enzyme } \\
\text { activity(U/ml) }\end{array}$ & $\begin{array}{l}\text { Protein Conc } \\
(\mathrm{Mg})\end{array}$ & $\begin{array}{l}\text { Specific } \\
\text { activity(U/mg) }\end{array}$ & $\begin{array}{l}\text { Fold } \\
\text { Purification }\end{array}$ \\
\hline Crude & 0.106 & 0.056 & 1.9 & 1 \\
\hline $\begin{array}{l}\text { Ammonium } \\
\text { Sulphate }\end{array}$ & 0.126 & 0.080 & 2.44 & 1.28 \\
\hline Dialysis & 0.071 & 0.025 & 2.9 & 1.52 \\
\hline Gel filtration & 0.145 & 0.010 & 14.5 & 7.6 \\
\hline Ion Exchange & 0.157 & 0.010 & 15.7 & 8.2 \\
\hline
\end{tabular}


The purity of alkaline phosphate enzyme was determined by Ploy acrylamide gel electrophoresis to get single band of monomer protein (Laemmli,1970). 97.4 Kda , $66 \mathrm{Kda}$ and $43 \mathrm{kda}$ markers used to identify the plant materials molecular weight.(Fig-1,Fig-2,Fig-3)

Fig-1: Urginea indica

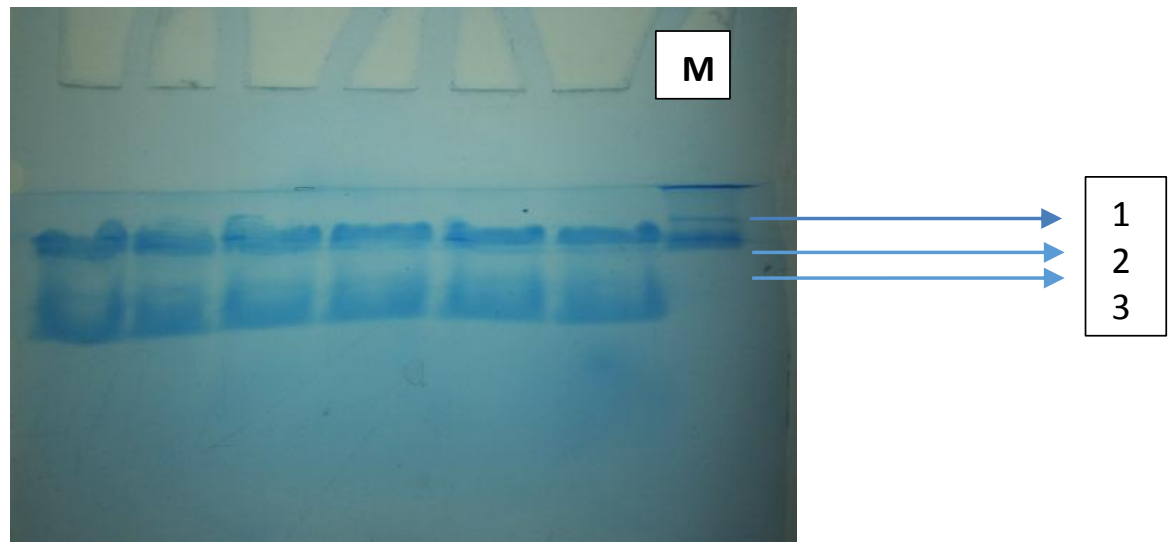

Fig-2: Urginea wightii

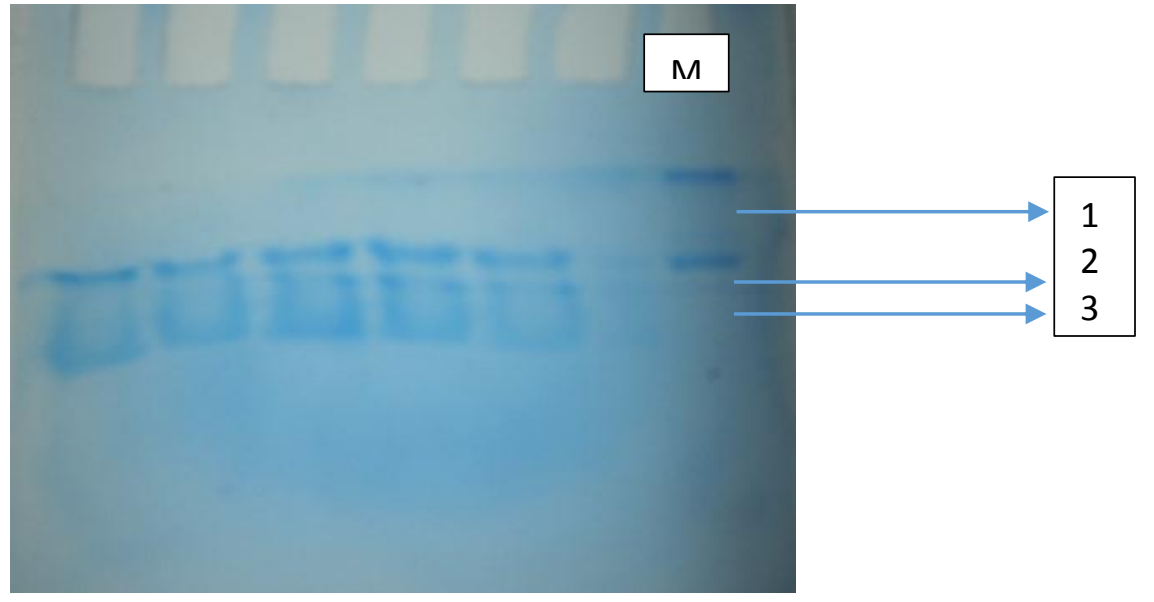

Fig-3: Urginea polyphylla

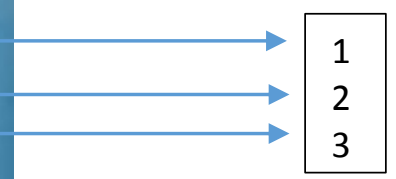




\section{1. $97.4 \mathrm{kDa}$}

\section{2. $66 \mathrm{kDa}$}

\section{3. $43 \mathrm{kDa}$}

Characterization studies thermostable alkaline phosphatase from various plant seeds have undertaken [13]. They have studied ion exchange chromatography on a DEAE Sephadex column, calibrated using standard proteins, showed that alkaline phosphatase had an unexpectedly high alkaline content. Characterization of alkaline phosphatase from the seeds of Dacryodes Edulis (African pear) has been studied [14]. They have activated alkaline phosphatase by $\mathrm{Mg} 2+$, $\mathrm{Mn} 2+, \mathrm{Ca} 2+$ and inhibited by EDTA and fluoro oxalate in a concentration dependent manner. Purification and Characterization of an Alkaline Phosphatase Induced by Phosphorus Starvation in Common Bean (Phaseolus vulgaris L.) Roots has been studied by Lorena Morales [15]. The estimated molecular mass of Alkaline phosphatase was $35 \mathrm{kDa}$ by both SDS-PAGE and gel filtration analyses, suggesting a monomeric form of the active enzyme in common bean whereas in Urginea species Urginea indica was found $46 \mathrm{kDa}$, Urginea wightii and Urginea polyphylla showed $43 \mathrm{kDa}$ molecular weight. Purification and characterization of alkaline phosphatase enzyme from periplasmic space of Escherichia coli C90 has been studied by A. Faiza Ali and B. Nada Hamza Hamza (2012). Extracellular alkaline phosphatase from Proteus Mirabilis was studied by Mahesh M, [16]. They have estimated molar mass by $12 \%$ SDS-PAGE and got nearly about 56KDa. Production, Purification and efficacy determination of Epsilon toxin from Clostridium has been studied by Richa Tiwari.17]. They have used salt precipitation, dialysis and DEAE sepharose separation method for purification and $10 \%$ polyacrylamide gel;Coomassie blue staining to analyses the purified epsilon -toxin.

\section{CONCLUSION}

In Urginea indica and Urginea polyphylla enzyme activity is more while Protein concentration was less compared to other species. Contrarily in Urginea wightii enzyme activity is less and Protein concentration was highest. Therefore, here the enzyme activity is not directly proportional to protein concentration. Genetically Urginea indica and Urginea wightii are not closely related with respect to chromosome numbers. Urginea indica $2 \mathrm{n}=30$ (triploid) and Urginea wightii $2 \mathrm{n}=20$ (diploid) while Urginea polyphylla $2 n=54$ (aneuploid). The contrasting difference observed in enzyme activity and Protein concentration may be attributed for the difference in gene expression of the Isozymes.

In the present study the extracellular Alkaline phosphatase from bulb extracts of three species of Urginea was identified and further investigation is required to make use of the potential of these medicinal plant for the production of the alkaline phosphatase by genetic engineering techniques.

\section{ACKNOWLEDGEMENT}

The first author is thankful to Department of Science and Technology(DST), New Delhi for providing financial assistance and Department of Botany, Bangalore University Bangalore for the laboratory facilities.

\section{REFERENCES}

[1]. Lianna Munson and R.Ray fall, "Purification and characterization of Escherichia Coli alkaline phosphatase. A biochemical experiment. Biochemical education", Volume 6 , Issue 3, pp.53-56, 1978.

[2]. A.Faiza Ali and B. Nada Hamza, "Purification and characterization of alkaline phosophatase enzyme from the periplasmic space of Escherichia coli C90 using Different method", African crop science Journal, Volume 20, Issue 2, pp.125-135,2012.

[3]. J.L. Millan," Alkaline phosphatases: structure, substrate specificity and functional relatedness to other members of a large superfamily of enzymes, Purinergic Signalling". via Springer, Volume 2, pp. 335-341, 2006.

[4]. H.K. Airy shaw, "Diagnosis of new families, new names etc. for the seventh edition of wills Dictionary" Kew Bull, Volume 18, pp.249-273, 1964;

[5]. D.B. Deb, S. Dasgupta, "On the identity of three new species of Urginea(Liliaceae", Journal of Bombay Natural History society, Volume 84, Issue 2, pp.409-412, 1987.

[6]. E Bernt, "Methods of Enzymatic Analysis (Bergmeyer HU, editor) $2^{\text {nd }}$ edition", Volume 2, pp.868-870, 1974.

[7]. O.H. Lowry, N. J. Rosebrough, A.L. Farr, and R.J. Randall, "Protein measurement with Folin-Ciocalten's reagent", Journal of Biological Chemistry, Volume 193, pp. 265-275, 1951.

[8]. A.W. Hodson, and A. Latner, "Isoenzymes of Alkaline Phosphatase". British Medical Journal Website:pubmed central.nih.gov ,Volume 2 ,pp. 5243-246, 1961.

[9]. G. Greene, H. Radhakrishna, and R. Tannenbaum, "Protein binding properties of surface modified porous polyethylene membranes". Biomaterials Volume 26, pp.5972-5982, 2005.

[10]. Laemmli UK. "Cleavage of structural proteins during the assembly of the head of bacteriophage T4", Nature, pp. 227: 680, 1970.

[11]. S.A. Miller, D.D.Dykes and H.F.Polesky, "A Simple Salting Out Procedure for Extracting DNA from Human Nucleated Cells", Nucleic Acids Res., Volume 16, Issue 3, pp. 12-15,1988.

[12]. Vemuri Praveen Kumar et al. "Characterization studies of thermostable alkalinephosphatase from various plant seeds", Journal of Applied Biosciences, Volume 36, pp.2403- 2408 ,2010.

[13]. Fajana Olusegun et al. "Characterization of Alkaline Phosphatase (E.C 3.1.3.1) From the Seeds of Dacryodes Edulis (African Pear) A Likely Industrial Source for Enzyme Production", International Journal of Engineering and Science, Volume 2 Issue 4, pp.31-36, 2013.

[14]. Lorena Morales et al. "Purification and Characterization of an Alkaline Phosphatase Induced by Phosphorus Starvation in 
Common Bean (Phaseolus vulgaris L.) Roots", J. Mex. Chem. Soc, Volume 56, Issue 1, pp. 80-84, 2012.

[15]. M. Mahesh, R. somashekhar, Preenon Bagchi and E.T. Puttaiah, "Optimization for the production of Extracellular Alkaline Phosphatase from Proteus mirabilis", Bioprocessing and Biotechniques, Volume 5, Issue 3, pp.1-5,2015.

[16]. Richa Tiwari Geetika Bakshi2, Niranjan Tiwari1 and Nitin Puranik "Production, Purification and efficacy determination of Epsilon toxin from Clostridium perfringens type 'D'IVRI native culture", International Journal of Scientific Research in Biological Sciences, Volume 2, Issue 2,pp.01-04,2015.

\section{AUTHOR PROFILE}

Banani Misra pursed M.Sc. Botany and currently pursuing Ph.D. in Botany from Bengaluru University, Bengaluru, India. She has published 3 research papers in reputed international journals. Her main research work focuses on Biochemical and Enzyme studies. She has 2+ years of teaching experience and $3+$ years of research experience. 